\title{
Resistance is fertile: exploring tiny house practices in Australia
}

\author{
Vicki Maree Weetman \\ School of Humanities, Languages and Social Science, Griffith University, Southport, Australia
}

\begin{abstract}
For many Australians, the current crisis in housing affordability and availability has created an impasse in relation to the dream of home ownership. Having begun in America in the 1990s and emerged relatively recently in Australia, the tiny house movement is largely positioned as a direct response to this crisis. Currently, there is little research on the motivations of those in the movement who are living in a tiny house on wheels (or THOW) or other unregulated tiny house options. Based on a qualitative multi-methodological study involving a number of Australian tiny house dwellers, builders and advocates, this paper examines Australian tiny housing trends like the THOW that are outside of current regulations, focusing on how they are lived and experienced among obvious grey areas in current planning, building and housing codes. Taking an interdisciplinary approach, it draws on multiple conceptual perspectives to open out a discussion that moves beyond affordability and availability discourses to argue that such tiny house trends also represent different resistant and spatialising practices within the dominant housing model, creating politically autonomous zones. Offering a novel morphology of informal architecture, I further suggest that these resistant practices invite the development of different planning approaches and practices.
\end{abstract}

\section{ARTICLE HISTORY}

Received 17 June 2019

Accepted 24 June 2019

\section{KEYWORDS}

Tiny house; THOW; minor architecture; becomingminor; resistance; informal architectures; interstitial housing practices

\section{Introduction}

Since the beginning of colonial occupation in Australia ownership of land and by extension a home has been valorised as an expression of both individual freedom and national identity. In the heady post-war period of the 1950s, growing independence from British imperialism in the spirit of 'rebuilding a nation' galvanised political and economic forces towards increasing home ownership rates. The aspirational tagline of Great Australian Dream (hereafter GAD) captured the national imagination, producing home ownership, socially and culturally, as our birthright and a cornerstone of society (Allon 2008). Over successive decades, the Australian home has become idealised as a large, detached, family dwelling with a double garage and a yard for the kids in a suburban master planned estate. Neoliberalism has continued to encourage residential mobility via the GAD as a means for individuals to take control of their own upward social mobility (Coulter and Van Ham 2013) thus entwining home ownership with the performance of middle-class identities, status, and ideals of respectability. Home ownership is therefore a strong signifier of normality and of a commitment to participation in Australian society (Dowling and Power 2012; McGuirk and Dowling 2009; Parsell 2012). In current circumstances, this association of home ownership (the dream) with status and identity remains immanent even as in reality it increasingly recedes from ordinary Australians.
Public and academic discourse increasingly refers to the 'Great Australian Nightmare' (Kemeny 2013; Gallagher 2016; Gilbert 2011), a burden of debt that stifles the dream of the good life and wears people out in the everyday (Gallagher 2016; Berlant 2006). A general review of the literature across a range of disciplines reveals that the mechanisms which produce and re-produce understandings of home ownership and home ownership rates in Australia are deeply complex and diverse (Bessant and Johnson 2013; Cook, Davison, and Crabtree 2016; Morley 2000). Consensus within the literature, however, indicates that concerns over home ownership or low rates of home ownership coalesces around two issues: affordability and the impact of rapid social change on preferences concerning traditional life course and housing trajectories (Allon 2008; Cook, Davison, and Crabtree 2016; Dowling and Power 2012; Gleeson 2008). Persistent concerns regarding housing affordability, directly linked to the dream of homeownership slipping from the grasp of many, are also at the forefront of the contemporary tiny house debate (Anson 2014; ; Precel and Adoranti 2015; Shearer 2017).

The contemporary tiny house phenomenon is selfdescribed as a social movement for people who wish to downsize, or live simpler lives. The origins of the movement have been traced to the United States in the late 1990s when Jay Shafer, the popularly acclaimed 'founder' of the contemporary tiny house movement, 
built his first very modest tiny house $\left(8 \mathrm{~m}^{2}\right)$, a reimaged cabin on wheels (Dirksen 2009). While Shafer maintains that tiny houses are nothing new, his rustic tiny house on wheels (hereafter THOW) has since become recognised as the archetypical style for tiny houses in the public imagination. Following in the wake of a threefold crisis encompassing the GFC, the housing crisis, and deepening concerns over climate change, the spread of the tiny house movement is also argued to be a direct response to housing affordability issues and increasing housing unsustainability - the excessive embodied energy, operational costs and environmental impacts involved with building conventional homes (Anson 2014; Boeckermann, Kaczynski, and King 2018; Negrin 2009; Evans 2018). Other motivations include a simplified lifestyle (Boeckermann, Kaczynski, and King 2018), mobile and flexible lifestyle options, a sense of community within the tiny house movement, and the creative selfexpression and sense of accomplishment a tiny DIY house build offers (Mutter 2013).

The definition of a tiny house remains open to interpretation. Tiny house advocacy organisations in America and Australia have worked towards a standardised definition for a tiny house as a built home, usually on wheels under $37 \mathrm{~m}^{2}$ (Mitchell 2014). While the THOW has become the poster child for the movement, a closer investigation of people who self-identify as living tiny' and having a tiny house reveals that the practice of tiny living is not confined to the THOW form alone. The diverse range of tiny house forms which come under the umbrella of the tiny house movement means that in effect, what constitutes a tiny house is determined by the occupant not by a standardised definition but is generally a dwelling space that has tiny dimensions and is under $37 \mathrm{~m}^{2}$. It can include: shipping containers, transportable/mobile homes, shed conversions, huts, cabins, yurts, studio trucks, caravans and even vans and cars (often referred on social media using the hashtags \#vanlife or \#carlife).

Tiny housing is not uncommon and has been a long-held legitimate practice, particularly in Australia and it is important to avoid any ambiguity in the use of the term 'tiny house' or 'tiny house movement'. Continuing from its origins as a social movement of resistance to housing norms the discussion in this paper refers directly to the forms and practices of tiny housing that can be characterised as non-standard and illegitimate. That is to say they are not, as yet, legitimate forms or housing practices existing interstitially in the grey areas between legality and illegality. For the purposes of clarity and as a distinction from legitimate forms of tiny house and housing practices (such as accessory dwellings) I have employed an acronym 'ITH' whereby 'I' represents the raft of terms interstitial, illegitimate or informal (TH tiny house) which currently includes the THOW, to highlight this condition of inbetweeness. Needless to say, of all the types of ITH the THOW is the most prevalent and readily recognised, and remains central to this discussion in terms of the majority of participant experience, public perceptions and existing academic research.

Within Australia, advocacy groups are currently lobbying towards formalising regulations for the THOW and its possible inclusion as a legal option for housing stock ("Australian Tiny House Association," 2018). These hybrid houses are able to eschew building codes for a habitable building by being comparatively classed as caravans. However, this classification does not exclude them from local codes or laws pertaining to living in caravans that are parked in residential areas or the construction standards for caravans (VSB1). Given the relative classification, advocates reject characterising a THOW as a caravan, maintaining that a THOW is a house with the aesthetic and animus of a real home (i.e., a permanent home).

Despite advocacy groups working for inclusion of the THOW into planning/zoning laws, it and other forms of the ITHs mentioned above do not conform to any current building or planning regulations and certainly not those applying to the main or primary residence. Dwelling practices in ITHs follow an ethos of build first: permissions and/or compliance are secondary and often considered only after the dwelling has attracted attention from local government. From this perspective the contemporary tiny house movement with its radically interstitial housing practices, offers new paradigms for urban planning and theory.

Existing scholarship on tiny houses is limited, almost entirely based on the phenomenon in the United States and generally focused around the THOW. A review of the literature identifies that tiny housing is frequently presented by its proponents as a paradigm-shifting, anti-capitalist approach able to supply all that is necessary for happiness and the good life (Anson 2014; D'Amico 2016; Ford and Gomez-Lanier 2017). These promises, alongside other claims of simplicity, sustainability and freedom, are critiqued by scholars as manifestations of 'Thoreauvian rhetoric', aspirational framing of what are still very conventional ideas of property ownership - an economic transaction in the market place (Anson 2014; D'Amico 2016). Additionally, this critique argues that, in effect, the freedom and autonomy associated with tiny houses can only be appropriated by privilege (Anson 2014; D’Amico 2016).

In its examination of the academic and public discourse surrounding tiny houses in Australia this paper offers an alternative reading of contemporary tiny housing as a practice of minor architecture through the process of becoming-minor, an in place fertile expression of resistance to the major model as represented by the GAD. As such it offers what is potentially a new morphology in informal architectures. 
This research has found that there are practices of tiny housing that remain hidden or overlooked in dominant housing discourses. These wider practices remain under-explored and arguably outside of a tiny house purview that seeks sanction and legislation. However, they invite further discussion particularly in the light of perspectives discussed below in terms of: becoming-minor; processes of deterritorialisation and reterritorialisation; and the productive return of difference. I therefore argue that, understood as a minor architecture, tiny housing, as it is practised and self-defined, is much more nuanced than the current research expresses.

\section{Methods}

The research in this paper has been conducted longitudinally over a period of 28 months and focuses on the micro-level lived experience involved in nine separate tiny house case studies. These included five couples, three families, and a not for profit foundation. The participants were contacted on multiple occasions over time and at various stages of tiny house life. Research methods are broadly ethnographic and significantly informed by the concept of 'cultural poesis' or the 'generativity of emergent things', whereby everyday and ordinary things are understood as intensely creative, laden with unknown effects and potentialities (Stewart in Denzin and Lincoln 2008, 565). Data has been collected through face to face and phone interviews with tiny house dwellers, builders and related industry professionals (designers, media personnel). It also includes participant observation in online groups and tiny house meet-ups and events, along with discourse analysis of media coverage of the tiny house phenomenon. The participants in the research were gathered through initial contact on social media pages and snowballing.

\section{Theoretical considerations}

The concept of a minor architecture emerges from Gilles Deleuze and Felix Guattari's work on Kafka, and their concept of minor literature. For Deleuze and Guattari (1986, 2011), a 'minor' is characterised as having three attributes: it has a high co-efficient of deterritorialisation; it is intensely political; and it produces an expressly collective enunciation. A minor (literature, architecture) does not occur elsewhere or outside but is always at work on the inside of the major using all the same elements, albeit in a different manner. Deleuze and Guattari employ the hyphenated term becoming-minor to articulate a minor, since all minors are becomings, in the sense that they resist closure and always produce movement within the major, namely a deterritorialisation of forms that have become fixed (O'Sullivan 2005). Jill Stoner (2012) examines minor architecture through the language of the masters', which she argues divides space into interiors and exteriors, or zones of inclusion and exclusion. Producing its own relative autonomy, the minor seeks to create 'new lines of causality and new pathways of experimentation' (O'Sullivan 2005). Janet McCaw $(1999,26)$ summarises the actions of a minor architecture in this way:

[T] he agenda of a minor architecture is much less heroic, seeking simply to subvert the privileges which usually prevail in architecture. Specific ownership and authorship are called into question by the collective process, the dominance of the visual is challenged by design decisions based on haptic experience rather than appearance... The question of what a minor architecture looks like cannot be answered. It could take many forms. A minor will be defined, not by its appearance, but by its ontology.

To utilise the concept of a minor architecture is to consider the ways in which tiny housing practices politically take apart the 'standards of architecture' or its signifying representations within the dominant system. More broadly, it must also examine the implications of this for taken-for-granted ideologies and frameworks which inform architectural theory and practice. The value of such minor perspectives is that they offer a re-reading of accepted understandings and knowledges. Positioning the tiny house phenomenon as an action of minor architecture provokes questions about the spaces it opens up in the dominant and normative narrative of housing and housing practices in Australia, alongside broader cultural notions of a safe haven, a right, and a safe as houses security for the future. From such perspectives this research considers the affective qualities of the tiny house phenomenon and the ways in which it seeks new forms of representation and new signifying regimes. These are not strategies towards standardising a new model but a continuous becoming-minor process of invention and creation.

\section{Tiny houses in Australia}

The contemporary THOW expression of tiny house living emerged in Australia only in recent history. As the poster child for the movement it is very much in the moment. Referencing the number of followers on various dedicated Facebook sites, tiny housing is often reported by the media as a rapidly growing phenomenon numbering in the tens of thousands. While it does seem to be almost ubiquitous online and in the public media, on the ground the number of tiny house dwellers in Australia is in fact significantly smaller. Even in the US, annual estimates from advocacy groups such as the Tiny Home Industry Association of industry sales figures for tiny houses on wheels - which are ostensibly higher than those of 
DIY builds - also indicate a phenomenon markedly disproportional to public perception (Schmidt cited in Sisson 2017). THOW proponents in Australia estimate that there are, at best, 100 tiny houses (on wheels) that are built or being built and possibly hundreds more that are flying under the radar (Hughes cited in Starkey 2017). Over the course of this research my survey of personal THOW build pages on social media and THOW builds shared on group sites located approximately fifty to sixty currently occupied THOW in Australia. Obviously, this finding is inconclusive: it cannot account for the proportion of ITH dwellers who do not engage with social media and/or are still building. Even if all anecdotal estimates were accepted as a real indicator of the size of the 'movement' in Australia, it is still infinitesimal (less than $1 \%$ ) when compared to the number of enthusiasts on social media. Demographic data collected from research participants and gathered from the aforementioned personal build page survey indicates that singles or couples in their 20s and 30s represent the largest population of THOW dwellers in Australia. The developing THOW industry may contribute to widening these demographics although it should be noted that given the legal precarity of ITHs, demographic data remains difficult to track.

Given that there is still no legislation specific to ITHs, a number of local government areas in Queensland, NSW and Western Australia have demonstrated a willingness to consider such tiny houses as another option towards increasing housing diversity (Brookes 2018; Jambor n.d.). In 2015, the Tiny House Foundation in partnership with the Gosford Shire Council (since amalgamated into the Central Coast Council) in NSW, launched a pilot project on council land to build four tiny houses for people at risk of or experiencing homelessness (“Tiny Homes Foundation," 2015). Completed in early 2018, the project set a precedent as the first DA approved tiny house project for the homeless in Australia. Still in the early stages of habitation, indications of the project's success are promising, however, since the local government merger, Central Coast Council remains circumspect on the approval of future projects (participant K 2017). In 2018, through the work of The Tiny Non-Profit, a grassroots advocacy organisation concerned with assisting councils towards the legalisation of the THOW, a collaborative Tiny Solutions exhibit was included in Melbourne Knowledge Week, an annual event providing a forum for new ideas and technologies towards imagining a better city ("Melbourne Knowledge Week," 2018). Tiny house open days were held in public spaces across the city. Each THOW on display catered to different needs. These included a custom build with accessible bathroom facilities and a remote-controlled, ceiling to floor, bed lowering mechanism suitable for aged care; a larger design with separate living and dining spaces; and a rustic off-grid cabin model designed specifically to cater to the tourism sector. These examples demonstrate that in terms of housing needs a THOW may fulfil many briefs:

I think I'm the most interested in tiny houses when people stick to them as an addition to fixed dwelling in that it's a small fixed dwelling, so that the housing in general, being both dwellings, can be more dynamic and can expand and contract as family expands and contracts over the years, and that's what excites me the most about it. Particularly when it comes to housing the elderly, I mean we have a big problem of an ageing population in Australia. It's pretty well discussed in academia but not so much in media and [the] general population and I think the tiny houses are pretty suitable option: if elderly parents become dependent then you can still have your base and sort of modify your living arrangements as needed. (participant A 2016)

As participant A points out, a THOW offers a more flexible and mobile option than the standard accessory building in the form of a 'granny flat' or 'studio shed'. The impermanence and mobility of a THOW allows it to be sold or moved to another site if current needs change. The tourism industry has also been quick to adopt tiny houses, usually marketed as off-grid, backto-nature experiences or a possible second income stream as Air BnBs (Barnes 2017). Tiny houses on wheels, in this respect are, small - spatially, economically, legislatively (although this remains a grey area); smart - incorporating sustainable, designs and green technologies; site-specific - able to fit in small spaces such as parking spaces and back yards and are flexible and adaptable to future change. As such, a THOW represents a temporary and transitional form of housing in step with the exigencies of contemporary social life. It must be noted though that the THOW is not the only form or practice of tiny house living. The growing industry surrounding the THOW attests to the capacity of capitalism, as the dominant system, to capture lines of flight and transform them into new commodified forms. The alternative material practices of tiny housing, however, retain deterritorialising processes which work to negate the signifying representations of the THOW as the model, or standard for tiny houses.

The origins and timeline of the contemporary ITH movement, as briefly outlined above, is also destabilised by becoming-minor impulses that reject an author or architect. As Shafer observes, tiny housing has always been around, but this research has found that much of the contemporary tiny housing phenomenon is far more collaborative, arising within a creative milieu which encourages non-conventional materials and approaches such as DIY builds; design sharing via open source building plans; utilising cross-industry technological solutions (for example marine and leisure camping); involvement with intentional communities, and informal economies of trade and barter; 
and connections with community activism and urban agriculture.

Regardless of its actual size, the ITH movement in Australia has widely penetrated the public imagination, growing steadily in its reach and influence since the first tiny house page, Tiny Houses Australia, launched in 2013. Testament to the current popularity can be seen in a recent example of a marketing scam thinly veiled as a THOW give-away, which exploded on Facebook - quickly amassing over 120,000 shares and garnering widespread media attention (Foster 2018). The rapid trajectory in tiny house awareness, from relatively unknown at the beginning of this research, three years ago, to mainstream status, can arguably be attributed to the 'viral transmission' of internet technologies networking the large volume of cultural production surrounding tiny house concepts, such as reality TV shows, YouTube channels, websites, blogs and social media sites (Castells 2015; D’Amico 2016). However, as this paper argues, there are also becoming-minor processes at work which remain unexplored and are possibly connected to broader ontological insecurities regarding notions of home.

\section{Participants' stories: resistance, refusal and flying under the radar}

In 2015, the ITH movement in Australia was very much in its infancy: many people had never heard of a THOW let alone seen one. Locating research participants in a fledgling movement was challenging. For many early-adopters privacy issues and concerns over the risk of exposure to authorities presented as barriers to joining the research project. Those who were willing to share openly about their experience of building and living tiny quickly became the tiny resource pool for anyone with an interest in the new phenomenon. Most of the participants in this research have also participated in other research or have been featured in public and social media. The small size of the available sample quickly, and not unproblematically, became well-traversed ground, inscribed by criss-crossed lines of rhetoric typically associated with tiny housing, such as housing affordability, sustainability, minimalism and anti-consumption.

From the outset all the participants in this research indicated that the normative housing narrative is not one that 'makes sense' to them or is even a sustainable option. For those living in large metropolitan areas, buying property seemed an outlandish proposition, one they refused to accept.

We get a lot of attention from hippy sorts and I don't really associate with their [ethos] ... Like they're all "screw the Government" and that sort of thing... I just want to do it for sustainability. I don't see how having multi-million dollar blocks of land, like this place is worth 1.5 million ... how's that a thing? (participant D 2016)

[S]o a couple of years ago the whole tiny house thing cropped up in the feed and it was like ... the penny really dropped. We thought, "Actually, this could be it, this could actually get us to where we want to be and actually be achievable and not based on this sort of future notion that one day we will earn enough money [so that] we can get something". (participant B 2016)

A THOW is not 'a new step on/into the housing ladder' since THOWs are not yet capital-creating, nor can they be utilised as a housing asset. In many ways choosing to live tiny in this way is a deferral of the ladder itself, with its linear trajectory and its narrative of successive steps towards social and financial mobility. In this project affordability emerges as the prevailing reason for living tiny, which largely corresponds with impulses towards freedom and lifestyle choice. Sensitivity towards environmental responsibility and sustainability also overlaps with many of the affordability discourses, constituting a synergistic admixture of motivations: 'We're not full-blown greenies but we are interested at having a go at being sustainable' (participant E 2016). Most, like participant $S$ (2016), viewed living tiny as the opportunity to explore and experiment with sustainability and selfsufficiency:

The intention was to live tiny and really sort of experiment with self-sufficiency and living off the grid.... I mean, the way things are going and just looking at the increase in the average house footprint and the amount of materials and embodied energy and operational costs and energy that goes into maintaining those houses and building those houses, I think it's unsustainable and it's a rethink in the way that we live. And really, what do we need to be happy? So, I'm interested in promoting maybe ... don't live in a THOW ... just rethink how much space you need and then think about the environmental and social benefits of that.

Over the course of this research it became apparent that living long term in a tiny house is not ideal or even desirable. For those living in a THOW, size restrictions mandated by the maximum height and width requirements for loads on trailers, presented challenges. The addition of a child prompted one couple to move on to a larger but still small dwelling. For some, the lack of space to physically spread out or retreat impacted upon them personally and in their relationships with each other, requiring negotiations around the ways they moved through and used the space available. Other issues included a lack of storage and thus clutter; insufficient water supply or hot water for showers; ongoing management of composting toilets and grey water systems; and the inability to entertain larger groups. Dealing with these frustrations, or as Anson $(2014,308)$ describes it, 'the sharp corners of tiny 
house living', were largely treated as opportunities for growth and creative solutions. As participant $\mathrm{M}$ (2017) discovered while experiencing discontent over certain issues such as a lack of space, it wasn't the house generating the discontent: the issue was with him trying to live a traditional housing narrative in a tiny house. He added, 'just by being here we kind of want for nothing really - day to day it's quite supportive, I think it gives more than it takes'.

Aspirational rhetoric online and in public media often portrays tiny houses as the new dream home, a narrative reminiscent of traditional housing ideals of stability, longevity or the forever home. This rhetoric is at odds with the lived experience of ITH owners. 'I think for most people, especially for us, it is an inbetween house. So, it's not a forever place' (participant E 2017). The temporal and transitional aspects of tiny house living in these cases operates as a creative and generative process of holding open the impasse currently posed by the affordability crisis in relation to the GAD, utilising non-destructive free-form mobilisations. Holding open the impasse is not merely a matter of holding space but a gestational process in which the participants undertake a revaluation of what contemporary life has to offer - even slow it down - or, as Deleuze and Guattari put it, 'make the language stutter'.

It's amazing when you start to explore these concepts and they start working on you. Like when I was in that space [Bluestone cottage], I started to realise that we spend our time in a couple of main areas and that all that the space between was the distance that we had to walk - pathways. And I thought, "wow if you squeeze them all together then you're going to end up with not much bigger than the room we're sitting in". (participant M 2016)

For these participants, building and living in a tiny house created space (if only temporarily) to radically question consumption and accumulation practices, re-think notions of property and property ownership, and take on the challenges of sustainability and ecological responsibilities. The tiny house becomes a space that re-invigorates imagination, offering new directions and possibilities. As one participant noted. ' $\mathrm{Y}]$ ou are so empowered by the whole experience of creating a home and everything that's necessary to live well ... there's a huge freedom and excitement and power in being able to do that' (participant $\mathrm{V}$ 2017). For these participants and indeed many others living a tiny life, a tiny house is not altogether a new model of the dream home in the neo-liberal project, as critiqued by Anson and D'Amico, it is an experiment towards dreaming differently.

In an interview, Shafer stated that a tiny house is 'not just a cute, twee little house', but is 'a form of civil disobedience for me.' Zoning and building codes, which he derides as 'mandatory consumption laws,' typically prohibit tiny dwellings. 'It's actually illegal to live in a very small house he said' (in "From the Home Front," 2011). Some twenty years after Shafer built his first THOW the contemporary ITH in form and practice continues to be illegal and unregulated in much of the USA. Similarly, in Australia, there is as yet no specific legislation concerning the building, or the habitation of a ITH as a primary dwelling, nor is there a real estate market for tiny houses that offers any appreciable capital gains. I would argue that while owning a tiny house 'free and clear' provides a sense of freedom and economic self-determination for the participants in this study, in this case home ownership does not conform with or correspond to the normative marketplace nor do ITH dwellers experience property ownership in the same way as those in standard housing forms. For ITH dwellers, home ownership is fraught with legal and regulatory uncertainty and insecurity. The few landmark favourable rulings in terms of living legally in a contemporary ITH are provisional and case-specific, yet a growing number continue to build/buy and live tiny, dwelling in the grey zone between the light of legality and the dark of eviction and dispossession. A question, then, remains as to why ITH practices and grassroots industries continue to grow on the ground and thrive in the public imagination despite the precarious landscape in which such tiny housing exists. In the context of a minor architecture the individual stories of each participant are intensely political, not fixated on an individual or domestic unit but connected to the larger social milieu. As one participant, J (2017) observes:

Tiny houses tap into a lot of veins of interest in the general public and so get media and attention. And people talk about it, more so than the number of people that it's a practical option for ... it's tied into a lot of sort of different drivers in our society in a lot of ways, in that people are dissatisfied with current society and disenfranchised with the housing system. So, it gets a lot of interest.

For these participants, choosing to live by flying under the radar in the grey areas and interstices of urban and peri-urban development and legislation is not a counter project but an internal displacement, through continuous improvisations with state logics effecting a spatial politics that opens up the cramped spaces of life.

My idea is like you were saying, flying under the radar - cause I'm creatively interpreting the legislature [i.e., legislation] that's out there. (participant H 2016)

I'm in the middle of a paddock with nothing else around except for a shed. Yes, I'm trying to fly under the radar.... The law has not caught up with the tiny houses yet. I think I need to do some more research though. If I have any issues I will just move on to a new spot. (Anon, Facebook post, 2017) 
In this respect, flying under the radar also operates as a practice of illegibility - a quiet refusal to become legible within State processes of standardisation and bureaucracy. Illegibility in this sense has been, and remains, a reliable source for political autonomy and an in-place line of escape (Scott in Halberstam 2011). Despite the risk of discovery and dispossession facing ITH dwellers there is a growing proliferation of ITHs in urban backyards and semi-rural or rural back blocks. This is a transgressive, creeping gain that enacts a political, micro-level, everyday resistance to accepted housing norms. Asef Bayat (1997) argues that illegitimate modes of building and housing or informal architectures represent a 'common sense approach' to individual housing needs that operate as autonomous zones. Kim Dovey $(2013,87)$, argues that 'our understanding of the urban and architectural morphology of informality is relatively undeveloped and often misunderstood.' While Dovey interprets informality to be a 'mode of production with varying levels of control by the urban poor' there are also respective readings of informality which include a notion of the casual or spontaneous; the condition of lacking a defined form and, occurring outside of what is prescribed. Certainly, in this manner an ITH in form and practice displays many characteristics of informal architecture. As Bayet, Dovey and others have argued, informal architecture and its intersections with formal architecture raises questions for urban planning and design, particularly in regard to policy and practice. Arguably these tiny house practices are producing a different morphology of informal architecture since they are not necessarily tied to poverty or minority groups in the same way as other understandings of informal architecture. This is to say, they are not limited to particular minorities: a minor is not a fixed social position and to construe it as such is a grave error. As Cindi Katz $(1996,491)$ points out:

[B]ecoming minor is open to anyone ... it entails a conscious effort to produce a subjectivity that simultaneously is "not at home" in a set of theoretical or other practices and refuses to be so. Thus, it attempts a political practice of refusal and reworking.

\section{Conclusion}

The founder of the future housing task force, Kevin Doodney, stated in an interview that we all have a problem in that we 'buy into a memory of architecture' but to solve the issues raised by the crisis in housing affordability and housing needs, 'we can't keep going back to what we've always had' (in Nazor 2016). He believes that more diversity in housing stock such as that offered by tiny housing will allow more Australians to achieve the great Australian dream of home ownership (Nazor 2016). This drive for tiny houses, specifically the THOW form, to be included as another housing stock option corresponds with earlier research which found that the ethos and aspirational promises of the early movement have been captured by the logics of capital. However, this research has sought to offer another reading of the contemporary tiny house phenomenon, in all its interstitial forms and practices, as a becoming-minor process of minor architecture. Further, I suggest that the dynamics of becomingminor and in place micro resistances such as flying under the radar, are instrumental as practices of minor architecture and, as such, are politically connected to the larger social milieu. By flying under the radar these tiny house practices act critically upon the major 'model' of the GAD through enactments of deferral, refusal and illegibility. They produce new narratives, built upon a different set of knowledges from those of the dominant system and contribute to a collective enunciation, the invention of a people who are already present but missing, 'masked by habitual modes of representation and commodified productions of subjectivity' (Deleuze and Guattari 2011; O’Sullivan 2005). Becoming-minors 'emerge from the interstices', are 'always on the brink of disappearing' yet are connected to different aspects of life and are 'full of transformative potential' (Katz 1996). While, saving money and saving the planet, is a central tenet for many who adopt tiny house living amongst the participants in this research and in the wider tiny house community, such motivations and the experience of tiny house living are far more nuanced and reflective, experimenting with ways to re-articulate the dominant discourse of normative housing in Australia and the neo-liberal subjectivity that accompanies it.

Urban planning, often viewed as a state apparatus of rationalisation, generates modes of resistance through the construction of 'exclusionary lines' across city spaces (Inch et al. 2017; Nicholls and Uitermark 2016; Yiftachel 2009, 2015). The ongoing and expanding informal and temporary uses of urban spaces, which must now include ITHs, strongly indicate that re-considerations of policy, governance and theory are warranted (Dovey 2010; Yiftachel and Huxley 2000). Jean Hillier (2007, ) and Mark Purcell (2013), who have engaged with Deleuze and Guattari in their approaches to planning theory, both acknowledge that, given that the corpus of planning theory is grounded on an ontologically defined existence of being, a becoming-ontology might seem counter-intuitive yet could be potentially groundbreaking for planning futures.

This paper has not sought to develop new theory but to offer a framework for thinking differently. Becoming-minor is a framework that affects a minor mode of thinking within the major, which in turn produces a critical stance towards planning through a refusal of mastery and processes of standardisation and opens a way for possible new and different knowledges. Finally, this paper suggests that such a critical stance, 
which seeks to work alongside and not outside of the people, should embrace an interdisciplinary process which includes the creative milieu: private and informal sectors, and can adopt smaller, site-specific approaches that are temporary, mobile and/or off-grid.

\section{Disclosure statement}

No potential conflict of interest was reported by the author.

\section{References}

Allon, Fiona. 2008. Renovation Nation: Our Obsession with Home. Sydney: UNSW Press.

Anson, April. 2014. “The World Is My Backyard': Romanticization, Thoreauvian Rhetoric, and Constructive Confrontation in the Tiny House Movement." In From Sustainable to Resilient Cities: Global Concerns and Urban Efforts, edited by William G. Holt, Vol. 14, 289-313. Emerald Group Publishing. http://www.emeraldinsight. com/doi/abs/10.1108/S1047-004220140000014013.

“Australian Tiny House Association." 2018. Accessed 30 December 2018. https://australiantinyhouseassociation. org.au/.

Barnes, Amelia. 2017. "We Live in a Tiny House: Meet the Teacher Who Built Her Own Home.” Domain, February 3. https://www.domain.com.au/news/the-victorian-highschool-teacher-who-built-her-own-tiny-house-20170202gu3rnp/.

Bayat, Asef. 1997. "Un-Civil Society: The Politics of the 'Informal People'." Third World Quarterly 18 (1): 53-72. doi:10.1080/01436599715055.

Berlant, Lauren. 2006. "Cruel Optimism.” Differences 17 (3): 20-36. doi:10.1215/10407391-2006-009.

Bessant, Judith C., and Guy Johnson. 2013. “'Dream on': Declining Homeownership among Young People in Australia?" Housing, Theory and Society 30 (2): 177-192. doi:10.1080/14036096.2012.728151.

Boeckermann, Lauren M., Andrew T. Kaczynski, and Sarah B. King. 2018. "Dreaming Big and Living Small: Examining Motivations and Satisfaction in Tiny House Living." Journal of Housing and the Built Environment, June. doi:10.1007/s10901-018-9616-3.

Brookes, Sarah. 2018. "City of Kalamunda Planning Officer to Investigate Tiny House Movement in US." Community News Group (blog), May 16. https://www. communitynews.com.au/kalamunda-reporter/news/cityof-kalamunda-planning-officer-to-investigate-tiny-housemovement-in-us.

Castells, Manuel. 2015. Networks of Outrage and Hope: Social Movements in the Internet Age. Cambridge: John Wiley \& Sons.

Cook, Nicole, Aidan Davison, and Louise Crabtree. 2016. Housing and Home Unbound: Intersections in Economics, Environment and Politics in Australia. New York: Routledge.

Coulter, R., and M. Van Ham. 2013. "Following People Through Time: An Analysis of Individual Residential Mobility Biographies." Housing Studies 28 (7): 10371055. doi:10.1080/02673037.2013.783903.

D'Amico, Christina. 2016. The Tiny House Movement. TEDx UofT. Accessed May 9, 2018. https://www.youtube.com/ watch? $\mathrm{v}=\mathrm{QWVgsK} 7 \mathrm{Uu} 3 \mathrm{k}$.

Deleuze, Gilles, and Felix Guattari. 1986. Kafka Toward a Minor Literature. Translated by Polan, Dana. Vol. 30.
Theory and History of Literature. Minneapolis: University of Minnesota Press.

Deleuze, Gilles, and Félix Guattari. 2011. A Thousand Plateaus: Capitalism and Schizophrenia. Translated by Brian Massumi. Repr. London: Continuum.

Denzin, Norman K., and Yvonna S. Lincoln, eds. 2008. Collecting and Interpreting Qualitative Materials. 3rd ed. Thousand Oaks, CA: Sage Publications.

Dirksen, Kirsten. 2009. Thoreau's Cabin Redux: Jay Shafer on Tiny Homes and Happiness. https://www.youtube.com/ watch?v=qaE4EvM-UF4.

Dovey, Kim. 2010. Becoming Places: Urbanism/Architecture/ Identity/Power. London: Routledge.

Dovey, Kim. 2013. "Informalising Architecture: The Challenge of Informal Settlements." Architectural Design 83 (6): 82-89. http://libraryproxy.griffith.edu.au/login? url=https://search.ebscohost.com/login.aspx?direct=true\& $\mathrm{db}=\mathrm{aft} \& \mathrm{AN}=91972610$ \&site $=$ ehost-live\&scope $=$ site.

Dowling, Robyn, and Emma Power. 2012. "Sizing Home, Doing Family in Sydney, Australia.” Housing Studies 27 (5): 605-619. doi:10.1080/02673037.2012.697552.

Evans, Krista. 2018. "Integrating Tiny and Small Homes into the Urban Landscape: History, Land Use Barriers and Potential Solutions." Journal of Geography and Regional Planning 11 (3): 34-45. doi:10.5897/JGRP2017.0679.

Ford, Jasmine, and Lilia Gomez-Lanier. 2017. "Are Tiny Homes Here to Stay? A Review of Literature on the Tiny House Movement." Family and Consumer Sciences Research Journal 45 (4): 394-405. doi:10.1111/fcsr.12205.

Foster, Sophie. 2018. "Thousands Fall for Tiny Home Giveaway Scam on Facebook." Accessed January 14, 2019. https://www.realestate.com.au/news/thousandsfall-for-tiny-home-giveaway-scam-on-facebook/.

"From the Home Front: Tiny Houses' Growing Popularity, Jay Shafer of Tumbleweed on Reinventing His Life, and the Politics of Very Small Homes." 2011. OregonLive.Com, March 25. http://www.oregonlive.com/hg/index.ssf/2011/ 03/from_the_home_front_tiny_house.html.

Gallagher, Katy. 2016. "The Great Australian Nightmare For First-Home Buyers.” Huffington Post, March 10. http://www.huffingtonpost.com.au/katy-gallagher/the-greataustralian-nightmare-for-first-home-buyers_b_9405632. html.

Gilbert, Travis. 2011. "The Great Australian Nightmare: Confronting Australia's Housing Affordability Crisis." Parity 24 (3): 30. http://search.informit.com.au/document Summary; $\mathrm{dn}=077433923972965 ; \mathrm{res}=$ IELFSC.

Gleeson, B. 2008. "Critical Commentary. Waking from the Dream: An Australian Perspective on Urban Resilience." Urban Studies 45 (13): 2653-2668. doi:10.1177/0042098 008098198.

Halberstam, Judith. 2011. The Queer Art of Failure. Durham: Duke University Press.

Hillier, Jean. 2007. Stretching Beyond the Horizon: A Multiplanar Theory of Spatial Planning and Governance. Aldershot: Ashgate.

Inch, Andy, Lucie Laurian, Clare Mouat, Ruth Davies, Benjamin Davy, Crystal Legacy, and Clare Symonds. 2017. "Planning in the Face of Immovable Subjects: A Dialogue about Resistance to Development Forces." Planning Theory \& Practice 18 (3): 469-488. doi:10. 1080/14649357.2017.1328811.

Jambor, Claudia. n.d. "Tiny Homes Welcome in Byron, but Not Vanpackers: Councillor.” Northern Star. Accessed January 7, 2019. https://www.northernstar.com.au/news/ tiny-homes-welcome-in-byron-but-not-vanpackers-cou/ 3236662/. 
Katz, Cindi. 1996. “Towards Minor Theory.” Environment and Planning D: Society and Space 14 (4): 487-499. doi:10.1068/d140487.

Kemeny, Jim. 2013. Housing and Social Theory. Hoboken: Taylor and Francis. http://grail.eblib.com.au/patron/ FullRecord.aspx? $p=178524$.

McCaw, Janet. 1999. "Architectural (s)Crypts: In Search of a Minor Architecture.” Architectural Theory Review 4 (1): 19-33. doi:10.1080/13264829909478357.

McGuirk, Pauline, and Robyn Dowling. 2009. "Neoliberal Privatisation? Remapping the Public and the Private in Sydney's Masterplanned Residential Estates." Political Geography 28 (3): 174-185. doi:10.1016/j.polgeo.2009.05.004.

. "Melbourne Knowledge Week Tiny Solutions." 2018. Tiny Non-profit. Accessed 29 June 29 2019. https://www.tiny.org.au/melbourne-home-show.

Mitchell, Ryan. 2014. Tiny House Living: Ideas for Building and Living Well in Less Than 400 Square Feet. New York: F+W Media.

Morley, David. 2000. Home Territories: Media, Mobility and Identity. Comedia: Routledge.

Mutter, Amelia. 2013. "Growing Tiny Houses: Motivations and Opportunities for Expansion Through Niche Markets." IIIEE Master Thesis. http://lup.lub.lu.se/student-papers/ record/4196241.

Nazor, Vezna. 2016. "Is America's 'Tiny Home Movement' Taking Hold Here?” SBS News. Accessed 16 January 2018. https://www.sbs.com.au/news/is-america-s-tinyhome-movement-taking-hold-here.

Negrin, Fiona. 2009. "Small Houses.” Sanctuary: Modern Green Homes 9: 24-26. http://www.jstor.org/stable/sanctuary.9.24.

Nicholls, Walter J., and Justus Uitermark. 2016. "Introduction: Planning/resistance." Urban Geography 38 (4): 512-520. http://dx.doi.org/10.1080/02723638. 2016.1168570 .

O’Sullivan, Simon D. 2005. "Notes Towards a Minor Art Practice.” Drain 2. http://drainmag.com/index_nov.htm.

Parsell, Cameron. 2012. "Home Is Where the House Is: The Meaning of Home for People Sleeping Rough." Housing Studies 27 (2): 159-173.
Precel, Nicole, and Kylie Adoranti. 2015. "Sick of Huge Mortgages? Meet the People Living Tiny for a Sustainable Future." Herald Sun. Accessed September 8, 2015. http://www.heraldsun.com.au/news/special-features/ living-small-the-tiny-house-movement-grows-in-australia/ story-fnllgf6j-1227279434817.

Purcell, Mark. 2013. "A New Land: Deleuze and Guattari and Planning." Planning Theory \& Practice 14 (1): 20-38. doi:10.1080/14649357.2012.761279.

Shearer, Heather. 2017. "Interest in Tiny Houses is Growing, so Who Wants Them and Why?" The Conversation. Accessed January 16, 2018. http://theconversation.com/ interest-in-tiny-houses-is-growing-so-who-wants-themand-why-83872.

Sisson, Patrick. 2017. "Are Tiny Homes More Hype Than Housing Solution?” Curbed, July 18. https://www.curbed. com/2017/7/18/15986818/tiny-house-zoning-aduaffordable-housing.

Starkey, Erina. 2017. "The Tiny House Movement Has Arrived in Australia." News, The Daily Telegraph, May 7. https:// www.dailytelegraph.com.au/lifestyle/home-mag/is-this-thesolution-to-sydneys-housing-affordability-crisis/news-story/ e3a895de4a13c0f484e37fbb1c4e4462.

Stoner, Jill. 2012. Toward a Minor Architecture. Cambridge, MA: MIT Press. http://site.ebrary.com/lib/alltitles/ docDetail.action?docID $=10537986$.

“Tiny Homes Foundation.” 2015. Accessed 10 June 2018 http://www.tinyhomesfoundation.org.au/.

Yiftachel, Oren. 2009. "Critical Theory and 'Gray Space': Mobilization of the Colonized." City 13 (2-3): 246-263. doi:10.1080/13604810902982227.

Yiftachel, Oren. 2015. "Epilogue-from 'Gray Space' to Equal 'Metrozenship'? Reflections on Urban Citizenship." International Journal of Urban and Regional Research 39 (4): 726-737. doi:10.1111/1468-2427.12263.

Yiftachel, Oren, and Margo Huxley. 2000. "Debating Dominence and Relevance: Notes on the 'Communicative Turn' in Planning Theory.” International Journal of Urban and Regional Research 24 (4): 907-913. doi:10.1111/14682427.00286 . 